\title{
可変速定周波独立運転形発電システムの新方式
}

\begin{tabular}{|c|c|c|c|c|}
\hline 正 員 & 川 畑 & 良 & 尚 & （大阪府立高尃 \\
\hline 非会員 & 森 根 & 義 & 久 & (立命館大学) \\
\hline 会 & 岡 & 寿 & 久 & （立命館大学） \\
\hline 員 & 川 畑 & 隆 & 夫 & (立命館大学) \\
\hline
\end{tabular}

\section{New Variable Speed Constant Frequency Stand-alone Power Generating System}

\author{
Yoshitaka Kawabata, Member (Osaka Prefectural College of Technology) \\ Yoshihisa Morine, Non-Member, Toshihisa Oka, Non-Member, \\ and Takao Kawabata, Member (Ritsumeikan University)
}

\begin{abstract}
Variable speed and constant frequency power generating systems using rotor excitation of the wound-rotor induction machines have been used for such applications as variable speed pump generators and flywheel energy storage systems. However, the stand-alone generating system of this type, has only been reported and has not yet been practically used.

On the other hand, the stand-alone generating systems using diesel engines have been widely used for emergency supply of plants or isolated islands and so on. However, in these cases, the synchronous generators are usually used. If the output frequency is to be kept constant, there is the need to control the speed of the engine using a high performance governor. Even then, the output frequency changes in case of a sudden load change.

This paper proposes a new stand-alone power generating system. In this system, the constant frequency output voltage can be obtained even though rotor speed changes by several percent.
\end{abstract}

キーワード：発電機，独立運転形発電機，可変速定周波発電，二次励磁，巻線形誘導機

\section{1.はじめに}

巻線形誘導機の二次励磁による可変速定周波発電方式は 可変速揚水発電やフライホイールエネルギー貯蔵などに害 用されているが(1)(2K3)，独立運転形の二次励磁発電システム は提案されているのみで(4)，実用はされていないようである。 エンジン駆動による独立運転形の発電機は，プラントの 非常用発電機や離島などの電源として広く利用されている。 これらの発電機は通常，同期機を用いているため，定周波 数を確保するには高性能ガバナでエンジンの速度を制御す る必要があるが，高性能ガバナを用いても，負荷急変時の 周波数变動が避けられない。また，エンジンの気筒数が少 ないと回転速度が一周期中で変化するので，それを軽減す るため重いフライホイールを設ける必要があるという問題 もあった。これらの問題点の解決策として，巻線形誘導機 のインバータによる二次制御方式があるが，独立運転形の 場合, 商用連采形上違って, 出力電圧を確立し, その周波 数と電圧を一定に保つという機能が必要となる。

そこで本論文では，この機能を有するシステムとして， 図1に示寸巻線形誘導機の一次側に負荷, 二次側に淔流電 源をバッテリとしたインバータを接続する独立運転形の二

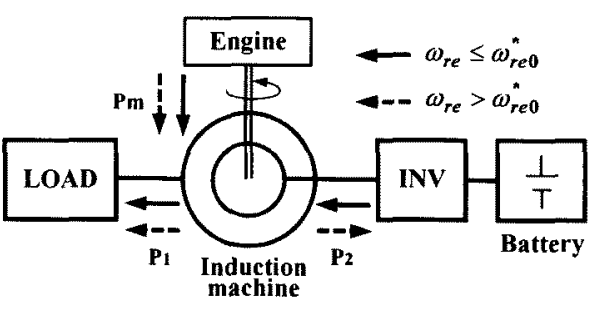

図1提案方式の主回路構成

Fig. 1. Proposed configuration.

次励磁発電方式を提案する。

本論文では，はじめに，提案する方式の原理抢よび構成 について述べる。次に，誘導機の二次制御方式の解析と設 計に適した手法として、マトリクス理論を適用した新しい 状態方程式を導入し，見通しの良い非干渉化制御系の設計 手法を提案する。さらに，電圧制御系の特性が負荷により 変化することを示し, それに対して安定な電圧制御系の設 計手法を提案する。最後に，モデル機による試験を行い， 原動機の回転速度が数\%変動しても出力周波数は全く変動 しない定電圧・定周波数の良好な特性が得られること孝検 証する。 


\section{2、基本原理と主回路構成}

图 1 に示した提案方式の主回路構成の特徽は, 二次 回路には 10\%以下程度のインバータとバッテリしか 設けず，充電器を不要にしたことである。

二次制御システムでは，同期速度より少し高い回転 速度で二次回路の損失がちょうど供給され，バッテリ が充放電しないバランス状態が得られるが，これを仮 に基準速度 $\omega_{r e 0}^{*}$ と名付ける。原動機の速度をこの基準 速度 $\omega_{r e 0}^{*}$ の前後でうまく制御することで, たとえ原動 機の速度が一時的に数\%変動しても,バッテリの充電 状態を自由に制御することができる。また、このイン バータとバッテリは原動機の始動に利用することが でき，通常必要な始動用のギヤードモータ，電池，お よびその充電器を不要にしている。

<2.1> パワーフロー

パワーフローは速度に応じて二つの状態がある。

速度 $\omega_{r e}$ が基準速度 $\omega_{r e 0}^{*}$ より低い場合では, 図 Iに 示すように，機械入力 $P_{m}$ とバッテリからの二次電力 $P_{2}$ により出力 $P_{1}$ （一次電力）が供給される。一方, 速度 $\omega_{r e}$ が基準速度 $\omega_{r e 0}^{*}$ より高い場合では, 機械入力 $P_{m}$ により出力 $P_{1}$ が供給され, 過鄱分が二次電力 $P_{2}$ と してバッテリを充電する。

このことからわかるように, 原動機の速度制御によ りバッテリを充放電できるので，バッテリ電圧 $v_{d c}$ は原動機 の速度指令を変化させることにより制御することができる。

すなわち，バッテリ電压 $v_{d c}$ がその指令值 $v_{d c}^{*}$ よりも小さ ければ，バッテリを充電するように，基準速度 $\omega_{r e 0}^{*}$ よりも 高速で回転させる。一方，バッテリ電圧がその指令值より も大きければ,バッテリを放電するように, 基準速度 $\omega_{r e 0}^{*}$ よ りも低速で回転させる。

\section{<2.2> インバータ容量}

原動機の速度変動を仮に同期速度を中心に数\%とすると， 二次側のインバータ容量は $10 \%$ 以下で良い。仮にインバー 夕容量を $10 \%$ 上すると, 誘導機の1次: 2 次の巻数比を 1: 10 とし，二次電流を 10 分の 1 にする。この場合，すべりが $10 \%$ 二次電圧は一次定格電圧と同じ，例えば $200 \mathrm{~V}$ となる ので，通常の電圧定格のインバー夕が適用できる。数十\%以 上の大きな負荷急変ですべりが 10\%以上になると二次電圧 は200V 以上となるが，そのような条件にならないようフラ イホイールの慣性とガバナの応答を選ぶ必要がある。

\section{3、制御系の原理と構成}

図 2 は DSP（TMS320C40，T.1.製）を用いて構成した制御 システムである。この制御系は，インバータの周波数・角 度演算部, 出力電圧制御部, 非干涉化電流制御部, バッテ

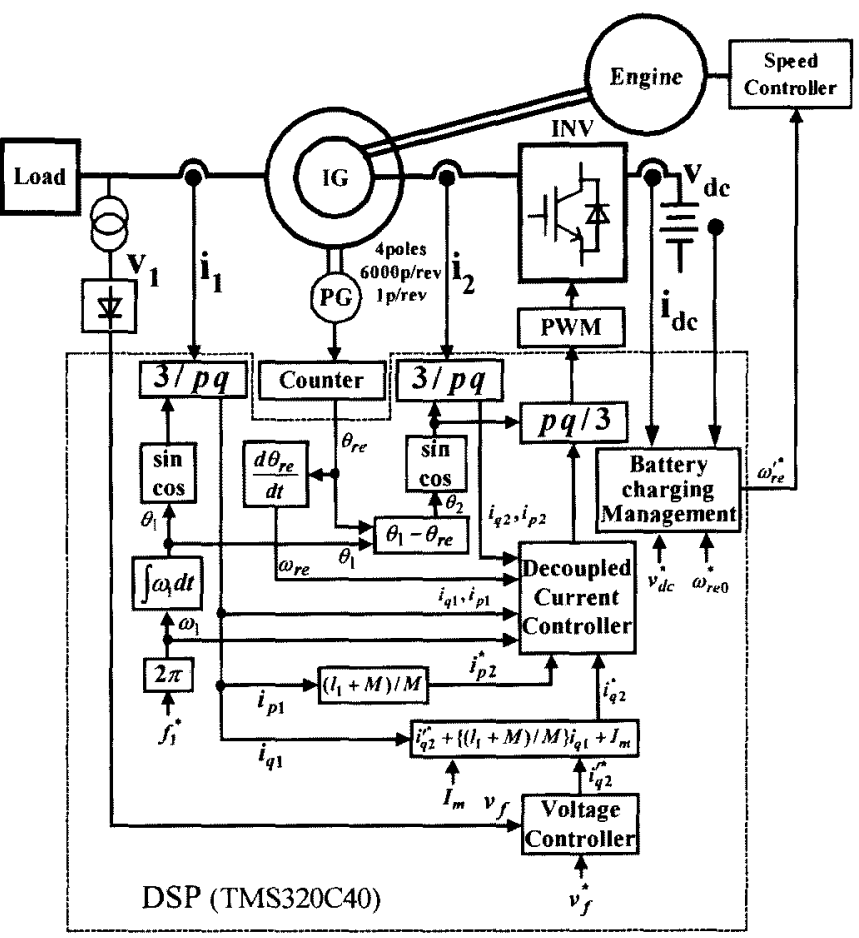

図 2 制悂系

Fig.2. Control system.

リの充放電管理部から構成されている。なお，本論文では， 発電機システム扱っているので，二軸直流成分を有効分 と無効分で論じるのがわかりやすいため，有効成分の軸を $p$ 軸，無効成分の軸を $q$ 軸としている。

誘導機の一次角度 $\theta_{1}$ は回転角度を $\theta_{r e}$, 二次角度を $\theta_{2}$ と すると，次式となる。

$$
\theta_{1}=\theta_{r e}+\theta_{2}
$$

この式から，回転数変動にかかわらず所定の一次角度 $\theta_{1}$ をもつ電圧を出力するためには， $\theta_{r e}$ に応じて $\theta_{2}$ を制御すれ ばよいことがわかる。すなわち，二次回路の電圧，電流は， 次式で決まる二次角度 $\theta_{2}$ 在座標基準とするインバー夕によ り制衙する。

$$
\theta_{2}=\theta_{1}-\theta_{r e}
$$

一次角度 $\theta_{1}$ は, 一次周波数指令 $f_{1}^{*}$ をとにソフトウエア で積分し，固定子のU 相の一周期ごとにリセットをかける ことにより求めている。この角度および $\sin , \cos$ テーブル を用いて，三相と $p-q$ 軸間の座標変換を行う。

回転角度 $\theta_{r e}$ は, 外部のカウンタで二相の 6000 パルス/回 軽 ( $\mathrm{A}$ 相，B 相パルス) と 1 パルス/回転の位置信号が得ら れるロータリエンコーダのパルスをカウントし，1 パルス। 回転のパルスでリセットをかけることにより得られる。供 
試機は 4 極であるため， カウンタの 6000 力 ウントが $720^{\circ}$ となる。

二次角度 $\theta_{2}$ は，(2)式により求め, この角 度および $\sin , \cos$ テーブルを用いて, 三相上 $p-q$ 軸間の座標变換を行う。

一次角度 $\theta_{1}$ は一次周波数指令をむとに作 成された一定周期の角度であり, 回転角度 $\theta_{r e}$ が変化しても, 二次角度 $\theta_{2}$ が $(2)$ 式に従 って自動的に変化するので，角度 $\theta_{1}$ は全く 影響を受けず一定周期を保つことができる。 仮に,エンジンが 6 気筒で 1 回転に 6 回のト ルク脈動が生じても, 上述の角度制御により, 一定の一次周波数を得ることができ，高い周 波数成分の速度変動に対しても定周波出力 を維持することができる。

一方, 定電圧制御に関しては，一次電圧検 出值 $v_{f}$ およびその指令值 $v_{f}^{*}$ 電压制御器 に入力し, 励磁電流の調整分の指令 $i_{q 2}^{\prime *}$ を得 る。また, 一次電流の無効電流成分 $i_{q 1}$ は変 圧器作用で二次と結合しており，二次に流寸

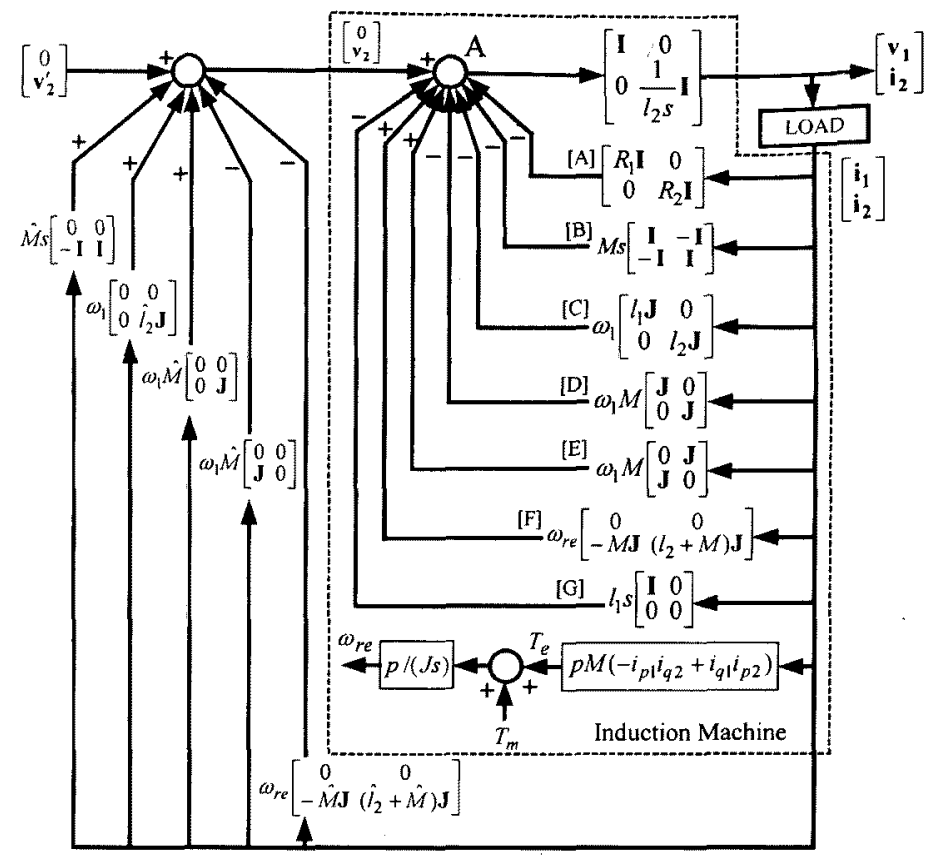

図 3 マトリクス表現をもちいた非干涉化制御 Fig.3. Decoupling control of induction machine.

必要がある。さらにあらかじめかかっている 励磁電流 $I_{m}$ も二次に流寸必要がある。した がってこれらの 2 つの成分をフィードフォワードし，イン バータの無効電流指令 $i_{q 2}^{*}$ は次式で与える。

$$
i_{q 2}^{*}=i_{q 2}^{i^{*}}+\left\{\left(l_{1}+M\right) / M\right\} \hat{i}_{q 1}+I_{m}
$$

上述のフィードフォワードを行うことにより，電圧制御 の応答が良くなる。

一次電流の有効電流成分 $i_{p 1}$ も変圧器作用で二次と結合し ており，二次に流す必要があるので，二次有効分電流指令 $i_{p 2}^{*}$ は， $i_{p 1}$ をフィドフォワードしを次式で与える。

$$
i_{p 2}^{*}=\left\{\left(l_{1}+M\right) / M\right\} i_{p 1}
$$

ここで，(3)，(4)式の一次電流の係数 $\left(l_{1}+M\right) / M$ は，一 次回路に流れる電流の無効成分と有効成分の干涉を補貲し, 一次電圧の伝達関数を簡単にするものである[付録 1]。

(3)，（4)式の電流指令を非干渉化電流制御器に入力し, 二相電圧指令を得る。その指令を座標変換して得られた三 相指令は PWM インバータの三角波比較器へ入力している。

\section{$<3.1>$ 誘導機の方程式}

$p-q$ 座標系に扔ける誘導機の電圧電流方程式は, マトリ クス表現を用いると(5)式のようになる(5)。ここで，発電機 動作のため一次電流は端子から出てゆく方向を正とし，二 次電流は端子から流入する方向正と定めている。

$$
\begin{aligned}
{\left[\begin{array}{l}
\mathbf{v}_{1} \\
\mathbf{v}_{2}
\end{array}\right]=} & \left(\left[\begin{array}{cc}
-R_{1} \mathbf{I} & 0 \\
0 & R_{2} \mathbf{I}
\end{array}\right]+\omega_{1}\left[\begin{array}{cc}
-l_{1} \mathbf{J} & 0 \\
0 & l_{2} \mathbf{J}
\end{array}\right]+\omega_{1} M\left[\begin{array}{cc}
-\mathbf{J} & 0 \\
0 & \mathbf{J}
\end{array}\right]\right. \\
& +\omega_{1} M\left[\begin{array}{cc}
0 & \mathbf{J} \\
-\mathbf{J} & 0
\end{array}\right]+P\left[\begin{array}{cc}
-l_{1} \mathbf{I} & 0 \\
0 & l_{2} \mathbf{I}
\end{array}\right]+P M\left[\begin{array}{cc}
-\mathbf{I} & \mathbf{1} \\
-\mathbf{I} & \mathbf{I}
\end{array}\right] \\
& \left.-\omega_{\mathrm{re}}\left[\begin{array}{cc}
0 & 0 \\
-M \mathbf{J} & \left(l_{2}+M\right) \mathbf{J}
\end{array}\right]\right)\left[\begin{array}{l}
\mathbf{i}_{1} \\
\mathbf{i}_{2}
\end{array}\right]
\end{aligned}
$$

$\beth こ て ゙, \quad \mathbf{I}=\left[\begin{array}{ll}1 & 0 \\ 0 & 1\end{array}\right], \quad \mathbf{J}=\left[\begin{array}{cc}0 & -1 \\ 1 & 0\end{array}\right], \quad \mathbf{i}_{1}=\left[\begin{array}{l}i_{q 1} \\ i_{p 1}\end{array}\right], \quad \mathbf{i}_{2}=\left[\begin{array}{l}i_{q 2} \\ i_{p 2}\end{array}\right]$, $\mathbf{v}_{1}=\left[\begin{array}{c}v_{q 1} \\ v_{p 1}\end{array}\right], \quad \mathbf{v}_{2}=\left[\begin{array}{c}v_{q 2} \\ v_{p 2}\end{array}\right]$ である。また, $R_{1}, R_{2}$ は抵抗, $l_{1}, l_{2}$ は漏れインダクタンス， $M$ は相互インダクタンス， $\omega_{1}$ は一 次角周波数， $\omega_{r e}$ は回転速度，Pは微分演算子である。なお， 簡単にするため，巻数比は 1 としている。

誘導機の出力方程式, 機械采の状態方程式はそれぞれ次 のようになる。

$$
\begin{aligned}
& T_{e}=p M\left(-i_{p 1} i_{q 2}+i_{q 1} i_{p 2}\right) \\
& P \omega_{r e}=p\left(T_{m}+T_{e}\right) / J
\end{aligned}
$$

ここで， $T_{m}$ は原動機駆動トルク， $T_{e}$ は発電機電磁トルク， $p$ は極対数である。また，発電機動作のため，一次電流は 端子から出て中く方向を正としているので, (6)式のトルク はマイナスとなる。 


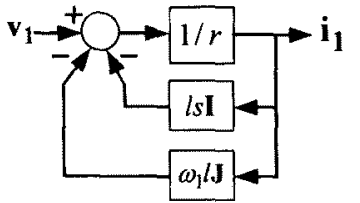

图 $4 r-l$ 直列回路急荷のブロック

Fig.4. Block diagram of $r \cdot l$ series circuit.

（５）式をもとに $\mathbf{v}_{\mathbf{1}}$ と $\mathbf{i}_{\mathbf{2}}$ に注目し，かつ加算点の入力が全 て電圧となるように変形すると次式となる。

$$
\begin{aligned}
{\left[\begin{array}{c}
\mathbf{v}_{\mathbf{1}} \\
P \mathbf{i}_{2}
\end{array}\right]=} & {\left[\begin{array}{ll}
\mathbf{I} & 0 \\
0 & \frac{1}{l_{2}} \mathbf{I}
\end{array}\right]\left\{\left(-\left[\begin{array}{cc}
R_{1} \mathbf{I} & 0 \\
0 & R_{2} \mathbf{I}
\end{array}\right]-\omega_{1}\left[\begin{array}{cc}
l_{1} \mathbf{J} & 0 \\
0 & l_{2} \mathbf{J}
\end{array}\right]\right.\right.} \\
& -\omega_{1} M\left[\begin{array}{ll}
\mathbf{J} & 0 \\
0 & \mathbf{J}
\end{array}\right]+\omega_{1} M\left[\begin{array}{ll}
0 & \mathbf{J} \\
\mathbf{J} & 0
\end{array}\right]-P l_{1}\left[\begin{array}{ll}
\mathbf{I} & 0 \\
0 & 0
\end{array}\right] \\
& \left.\left.-P M\left[\begin{array}{cc}
\mathbf{I} & -\mathbf{I} \\
-\mathbf{I} & \mathbf{I}
\end{array}\right]+\omega_{r e}\left[\begin{array}{cc}
0 & 0 \\
-M \mathbf{J} & \left(l_{2}+M\right) \mathbf{J}
\end{array}\right]\right)\left[\begin{array}{l}
\mathbf{i}_{1} \\
\mathbf{i}_{2}
\end{array}\right]+\left[\begin{array}{c}
0 \\
\mathbf{v}_{\mathbf{2}}
\end{array}\right]\right\}
\end{aligned}
$$

誘導機のブロックは( 6$),(7)$ および 8 )式から図 3 の点 楾で囲まれた部分となる。なお，このブロックでは加算点 $\mathrm{A}$ の入力部分は全て電圧となっているので, 物理的に理解し やすくなっている。

一次電流は，負荷とその印加電土で決まり，例えば，負 荷を抵抗 $r$ およびリアクトルlの直列回路とすれば，一次電 流は次式となる。

$$
\mathbf{i}_{1}{ }^{\prime}=\left(\frac{1}{l s+r}\right) \mathbf{v}_{1}^{\prime}
$$

ここで $i_{1}{ }^{\prime} ， \mathbf{v}_{1}{ }^{\prime}$ は三相座標采における電圧，電流である。

上式を $p-q$ 座標系における電圧 $\mathbf{v}_{1}$, 電流 $\mathbf{i}_{1}$ に変換し変 形すると，次式となる。

$$
\mathbf{i}_{1}=\frac{1}{r}\left\{\mathbf{v}_{1}-\left(l s \mathbf{I}+\omega_{1} l \mathbf{J}\right) \mathbf{i}_{1}\right\}
$$

直列回路負荷のブロックは(10)式から図 4 となる。

\section{$<3.2>$ 非干涉化制御法}

図 3 の誘導機のブロックには，電流の無効成分と有効成 分が干渉しているJを含んだマトリクス $[C],[D],[E],[F]$ および一次側と二次側の干渉を含んだマトリクス[E], [F], 無効成分と有効成分のそれぞれにおける相互インダクタン スによる一次回路と二次回路の結合を表すマトリクス $[\mathrm{B}]$ が 存在する。そこで,これらのマトリクスの二次側電圧に関 する(2,1)および(2,2)要素をキャンセルするため, 図 3 のよう にマトリクス $[\mathrm{B}],[\mathrm{C}],[\mathrm{D}],[\mathrm{E}],[\mathrm{F}]$ の二次側電圧に関する $(2,1)$ およひ(2,2)要素の逆符号を $\left[\begin{array}{ll}0 & v_{2}^{\prime}\end{array}\right]^{\prime}$ に加える。

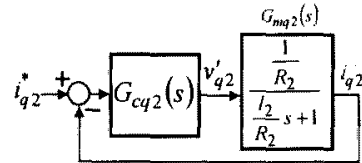

(a) 無効分電流

(a) Reactive current

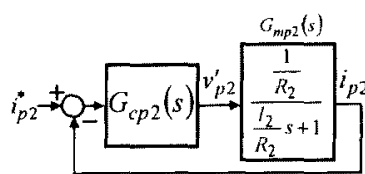

(b) 有效分電流

(b) Active current
図 5 誘導機の電流制御ブロック Fig.5. Current controller.

ここで，制御器における誘導機定数の設定值は，実際の 誘導機定数と異なるため, 制御器における誘導機定数の設 定值に”在付けて奉際の定数と区別している。

なお, マトリクス $[\mathrm{B}],[\mathrm{C}],[\mathrm{D}],[\mathrm{E}] \boldsymbol{O}(1,1)$ および $(1,2)$ 要 素にも無効成分と有効成分もしくは一次側と二次側の干涉 した成分が存在するが，一次側は電流制御ができないため, 補償の対象とはならない。

これらの非干渉化制御により，二次無効分電流と一次無 効分電流および有効分電流との干渉，もしくは，二次有効 分電流々一次有効分電流および無效分電流との干涉がなく なる。その結果，二次側の無効分電流上有効分電流は干涉 することなく独立して制御することができるようになる。

\section{$<3.3>$ 電流制御器の設計法}

非干渉化制御器における誘導機の設定值と実際の誘導機 定数が等しいと仮定した場合，非干涉化制御後の誘導機の 電流制御のブロックは図 5 のようになる。

こニで, $G_{c q 2}(s), G_{c p 2}(s)$ 注電流制御器の伝達関数であ り，次式で表すPI制御である。

$$
G_{c q 2}(s)=K_{q 2}\left(1+\frac{1}{T_{q 2} s}\right), \quad G_{c p 2}(s)=K_{p 2}\left(1+\frac{1}{T_{p 2} s}\right)
$$

[付録 2]に示す大形機定数の場合におらいて，無効分電流上 有効分電流の制御系の交差角周波数 $\omega_{c q}, \omega_{c p}$ を $1000 \mathrm{rad} / \mathrm{s}$ として各ゲインを求めると， $K_{q 2}=K_{p 2}=0.4, T_{q 2}=T_{p 2}=$ 0.0151 となる。

\section{$<3.4>$ 電圧制御器の設計法}

本提案方式では，インバータにより誘導機の二次電流を 制御することで一次電圧を制御するが，この電圧制御系の ブロックを描くと図6のようになる。

ここで， $G_{c f}(s)$ は電圧制御器の伝達関数で, 次式で表す PI 制御である。

$$
G_{c f}(s)=K_{f}\left(1+\frac{1}{T_{f} s}\right)
$$

一次電圧は, 一次無効分電圧 $v_{q 1}$ 上一次有効分電仼 $v_{p 1}$ \% 
ベクトル和 $v_{f}$ の大きさとして求めること ができ，次式となる。

$$
v_{f}=\sqrt{v_{q 1}^{2}+v_{p 1}^{2}}
$$

ここで, 一次電圧 $\mathrm{v}_{1}\left(=\left[\begin{array}{ll}v_{q 1} & v_{p 1}\end{array}\right]^{t}\right)$ は,

(8)式から次式となる。

$$
\begin{aligned}
\mathbf{v}_{\mathbf{1}} & =-\left\{\left(R_{1}+P\left(l_{1}+M\right)\right\} \mathbf{I}_{\mathbf{1}}-\omega_{1}\left(l_{1}+M\right) \mathbf{J} \mathbf{i}_{\mathbf{1}}\right. \\
& +\omega_{\mathbf{1}} M \mathbf{J i}_{\mathbf{2}}+P M \mathbf{I}_{\mathbf{2}}
\end{aligned}
$$

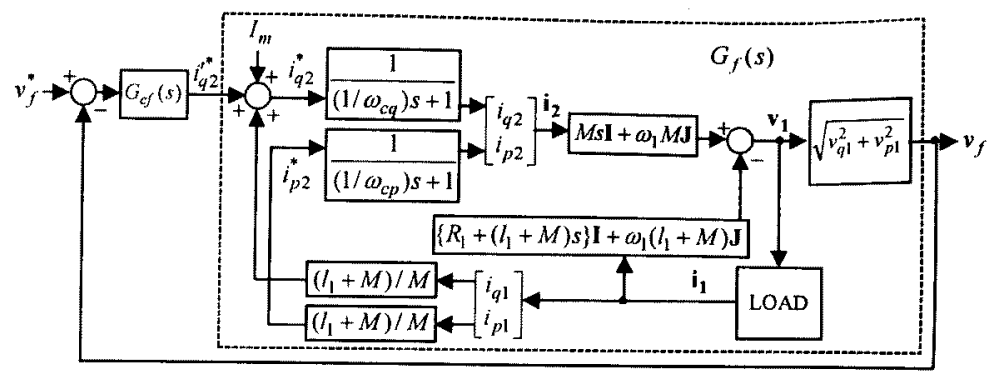

図 6 電圧制御のブロック図

Fig.6. Voltage controller.

(14)

電流制御がく3.3>で述べた設計通りに行えるとすると，二 次電流 $i_{q 2}$ および $i_{p 2}$ はその指令值 $i_{q 2}^{*} ， i_{p 2}^{*}$ を用いて次のよ うに表すことができる。

$$
i_{q 2}=\frac{1}{\left(1 / \omega_{c q}\right) s+1} i_{q 2}^{*}, \quad i_{p 2}=\frac{1}{\left(1 / \omega_{c p}\right) s+1} i_{p 2}^{*}
$$

(3)，(4)，(13)，(14)および(15)式から, 一次電圧 $v_{f}$ のブロックを描くと図6の点線で囲まれた部分となる。

$i_{q 2}^{*}$ から $v_{f}$ 八の伝達関数 $G_{f}(s)$ は，負荷によって変化する。 そこで代表的な以下の 3 種類の負荷についてその伝達関数 を検討する。

（i）遅れ力率 $90 \%$ 鱼荷時 $(r=1.15 \Omega$ と $l=0.0015 \mathrm{H}$ の直列 回路)

(ii) 遅れ力率 $70 \%$ 負荷時 $(r=0.90 \Omega$ と $l=0.0024 \mathrm{H}$ の直列 回路）

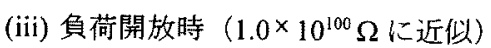

伝達関数 $G_{f}(s)$ を[付録 2]に示す大形機定数を用いてボ一 ド線図で表すと，図7の点線の(i)から(iii)のようになる。こ こで, 電流制御器の交差角周波数は, $\omega_{c q}=\omega_{c p}=1000 \mathrm{rad} / \mathrm{s}$ としている。

図7の(i)から(iii)のうち (i)および(ii)は角周波数 $500.0 \mathrm{rad} / \mathrm{s}$ でゲインに若干のピークがあり，他のものに比べ振動的な 応答になり易いのでこれれ合わせて図7 の実線のように 進み補償を入れる。この場合の電圧制御器の積分時間 $T_{f}$ は $0.002 \mathrm{sec}$ で, $G_{f}(s)$ との合成伝達関数は図 8 の点線のように なる。この伝達関数が交差角周波数 $\omega_{c f}=50 \mathrm{rad} / \mathrm{s}$ で $0 \mathrm{~dB}$ を

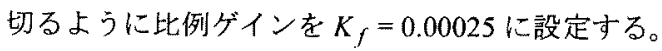

上記に述べた比例ゲインと積分時間に設定したときの(i) から(iii)の合成伝達関数のボード線図は図 $8 の$ 実線となり， いずれの負荷においても， $\omega_{c f} か ゙ ~ 40 \mathrm{rad} / \mathrm{s}$ から $70 \mathrm{rad} / \mathrm{s} の$ 範 囲となり，充分位相余裕があり，安定な特性が得られてい ることがわかる。
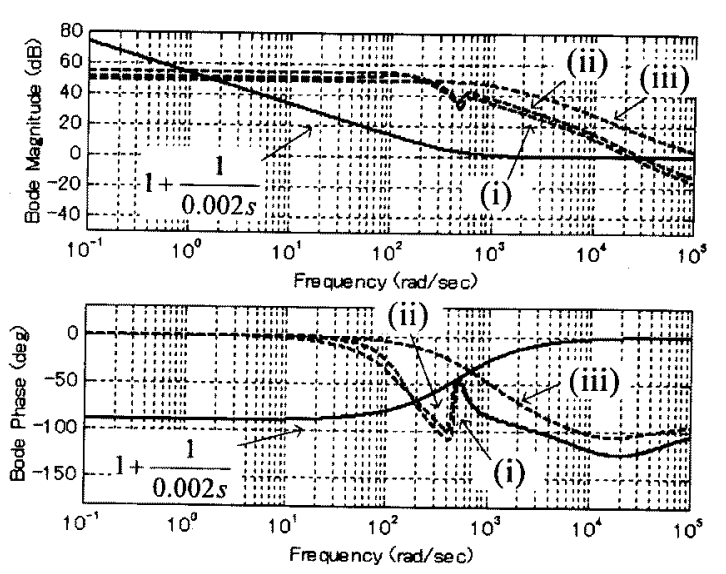

図 7 電圧オープンループ特性 (比例ゲイン調整前)

Fig.7. Open loop characteristic. (before a proportional gain adjustment)
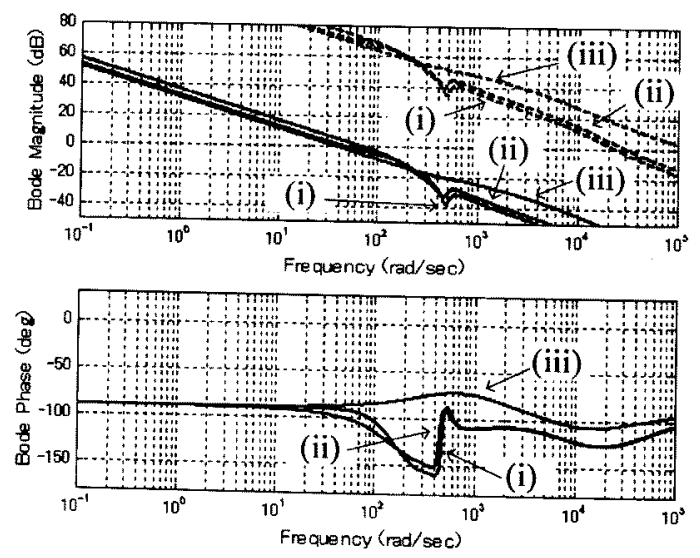

図 8 電圧オープンループ特性 (比例ゲイン調整後)

Fig.8. Open loop characteristic (after a proportional gain adjustment)

\section{<3.5> バッテリの充放電管理}

バッテリの充放電管理は, 図 9 に示す充放電管理システ ムにより，原動機の速度指令 $\omega_{r e}^{\prime *}$ を変化させることにより行 う。ここで, バッテリ電流 $i_{d c}$ は，バッテリへ流入する方向 を正としている。また, バッテリ電流指令值および速度指 


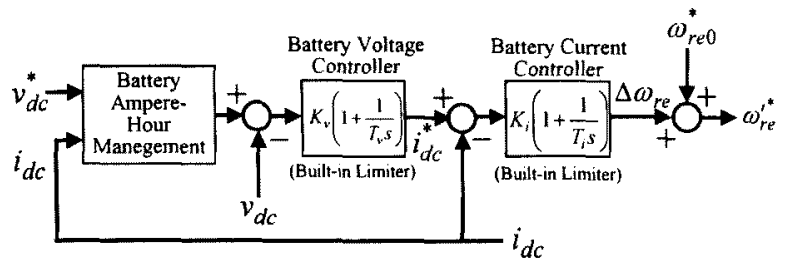

図9バッテリの充放電管理

Fig.9. Battery management.

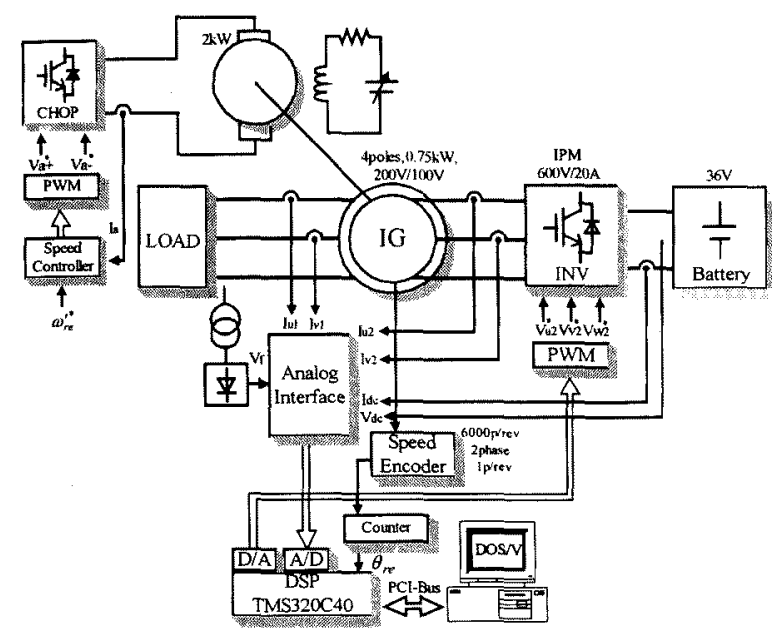

図 10 実験システム

Fig.10. System of experimental setup

令值が定格を越えないように，制御器にリミッタを内蔵し ている。

バッテリの電圧は，急速には変化しないので，速度制御 の応答性は緩やかなもので良い。バッテリの制御手順は以 下のとおりである。

（1）始動時にバッテリは満充電で100\%容量であるとすると 始動後すぐに $v_{d c}^{*}$ を下げ，バッテリを放電状態にする。

(2) (1)の間の放電 AH (Ampere Hour) 在積分し, 30\%程度 の $\mathrm{AH}$ を放電させ, バッテリが充電電流を受け入れるこ とのできる状態にする。

(3) 適切な放電 $\mathrm{AH}$ 老確認の後 $v_{d c}^{*}$ をもどして原動機の速度 を基準速度 $\omega_{r e 0}^{*}$ まで上げる。

(4) バッテリが平均的に充放電のない状態を保つように速 度を調整してバッテリの管理を行う。

\section{$<3.6>$ 誘導機の始動方法}

巻線形誘導機の二次側に接続されているインバータとバ ッテリは10\%速度まで $100 \%$ のトルクを確保できるので(6)(7), エンジン始動用に利用できる。誘導機の始動方法は以下の とおりである。

(1) 負荷スイッチが開いていることを確認する。

(2) 誘導機の一次側を短絡する。

(3) バッテリを電源としてインバータにより誘導電動機と

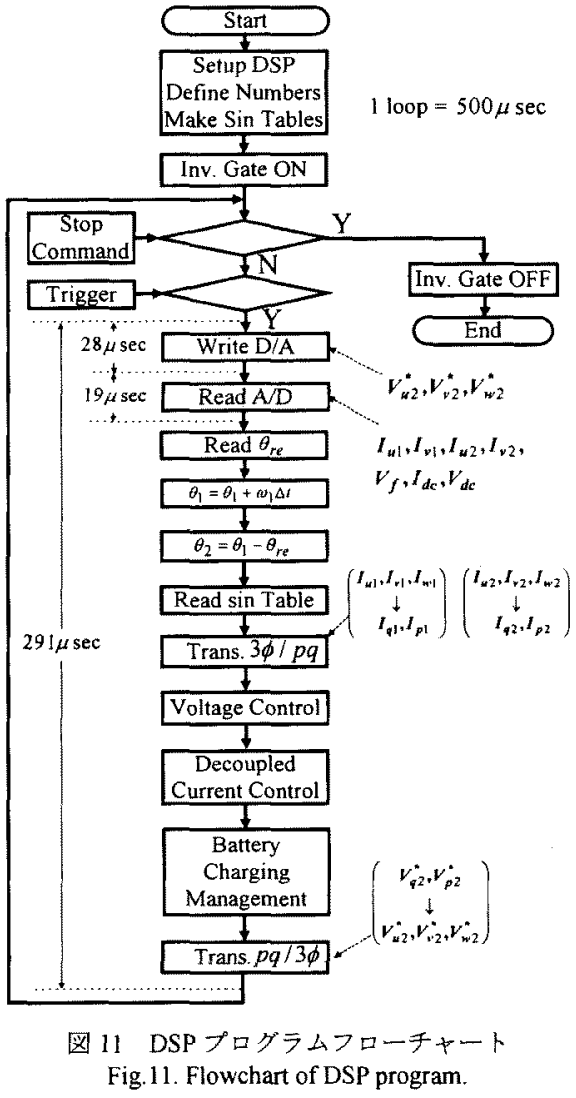

して動かし，原動機を始動する。

（4）始動すればすぐにインバータのダートを停止し，一次 側の短絡線を開く。

（5）原動機回転数を同期速度の近くまで上昇させる。

(6) インバー夕を運転し，電圧制御系を動作させ，一次電 圧が定格に達したら，負荷スイッチを閉じる。

\section{4. 検証試験のシステム構成}

検証試験のシステム構成を図 10 に示す。室内での実験で エンジンを使うことは騒音や排気ガスの点で問題があるの で，本研究ではチョッパにより速度制御できるようにした 直流電動機で代用している。

[付録 2]に示す供試譏定数をもつ巻線形誘導電動機を発電 機として用い，定格 $2 \mathrm{~kW}$ の直流機により駆動している。供 試機の巻数比は $2: 1$ であり，二次側のインバー夕容量は $10 \%$ 程度でよいので,インバータの直流電圧は $36 \mathrm{~V}$ 定格に下げ ている。

インバータと直流機のチョッパにはIPM（PM20CSJ060, 定格 $20 \mathrm{~A} ， 600 \mathrm{~V}$ ，三菱電機製）を使用している。

出力電圧の検出には変压器を用い, 入力チャンネル数の 都合により，外部回路で三相全波整流したものを 入力している。

DSP プログラムは C 言語で書かれており，そのフローチ 


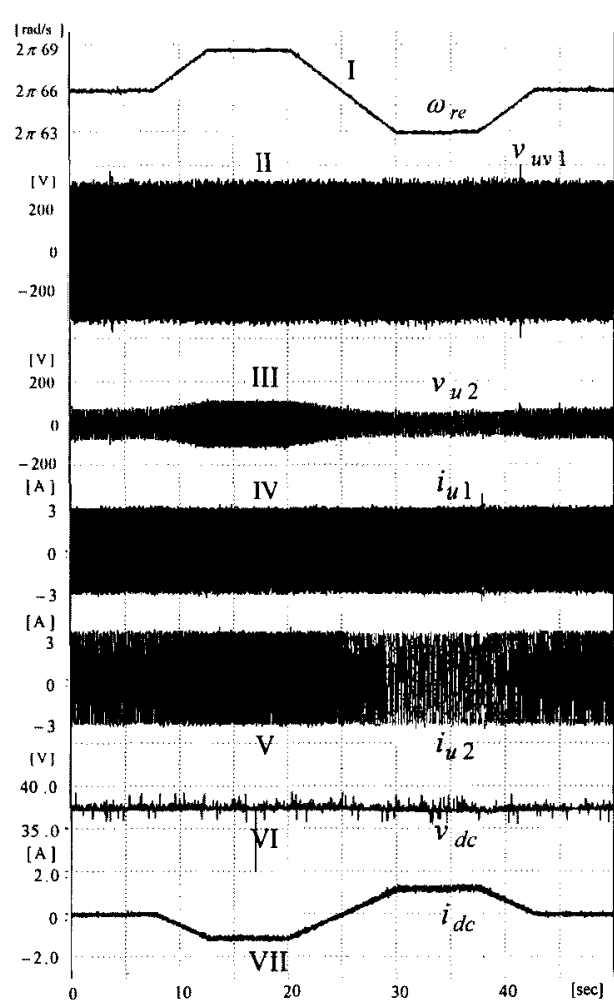

図 12 実験結果（回転速度変動試験） (速度, 電圧, 電流波形)

Fig.12. Experimental results of speed fluctuation operation (speed, voltage, current)

ヤートを図11に示す。

演算割り込みはインバータのキャリア $2 \mathrm{kHz}$ の正の頂点ご とに行い，演算周期は $500 \mu \mathrm{sec}(2 \mathrm{kHz})$ に設定している。 この 1 サンプリング内の入出力と演算の所要時間には充分 余裕があり，291 $\mu \mathrm{sec}$ でサンプリング時間の $58 \%$ 以下であ る。

回転角度 $\theta_{r e}$ と速度を検出するため, 二相の 6000 パルス/ 回転と 1 パルス/回転の位置信号が得られるロータリエンコ 一ダ (RP-112AZ0, 小野測器製) を用いている。角度 $\theta_{r e}$ は, 5999 カウントのカウンタにより求めているが，供試機の極 数が 4 であることを考慮して, 6000 パルスが電気角の $720^{\circ}$ となるようにしている。

このカウンタに初期位置情報を与えるために，直流電動 機で少なくとも 1 回転させ，二次のU 相と一次のU 相が一 致したときにリセットがかかるように1パルス/回転のパル ス位置を調整する。

回転速度 $\omega_{r e}$ は, 角度 $\theta_{r e}$ を微分することにより求められ

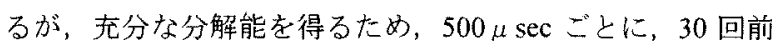
すなわち $15 \mathrm{msec}$ 前の角度情報と現在の角度との偏差をとる ことにより求めている[付録 3]。

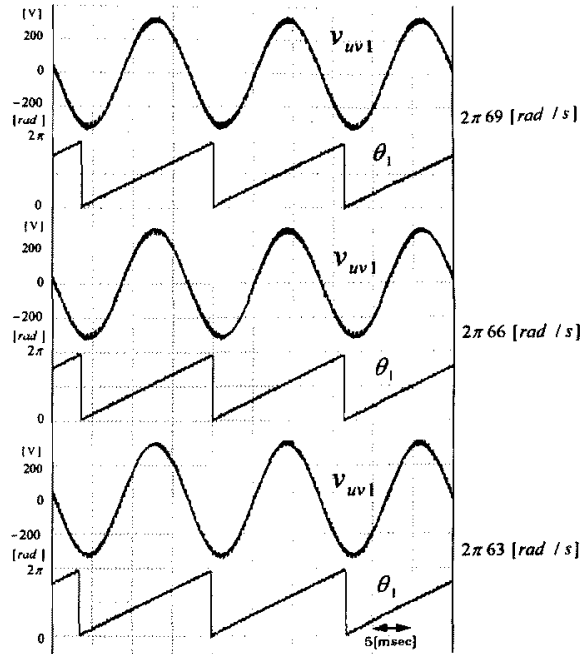

图 13 実験結果（回転速度変動試験） (一次電圧, 角度波形)

Fig.13. Output voltage and electrical angle at various speed.

\section{5. 検証試験の結果}

\section{$<5.1>$ 回転速度変動試験}

回転数を変動させる実験を行った。その結果を図 12 に示 す。

図 12 の波形 II 以外の信号は DSP の内部信号を出力した ものであるが, 出力チャンネル数の都合により, 以下の組 み合わせで 4 回の同一条件の実験を行い記録した。

I, II と III, IV と V, VI と VII

加減速のタイミングはソフトウエアで自動的に決めてお り, 電流制御器および電圧制御器のパラメータは前述の $<3.3>$ ， <3.4>の設計法により求めた值に設定した。

負荷は抵抗 $50 \Omega$ とリアクトル $8.7 \mathrm{mH}$ の直列回路（定格負 荷の $77 \%$ ，力率 54\%）とした。

速度指令は傾斜信号を設けて $2 \pi 66 \rightarrow 2 \pi 69 \rightarrow 2 \pi 63 \rightarrow$ $2 \pi 66 \mathrm{rad} / \mathrm{s}$ と $5 \mathrm{sec}$ 間で加減速を行っている。

II と III は一次線間出力電圧および二次相電圧の波形であ るが、二次制御により一次線間電圧の振幅が一定に制御で きていることがわかる。

VI と VII はバッテリの電圧おうよび電流の波形であるが, 速度が $2 \pi 66 \mathrm{rad} / \mathrm{s}$ 以上のときは充電, $2 \pi 66 \mathrm{rad} / \mathrm{s}$ 以下のとき は放電していることがわかる。この速度を基準速度 $\omega_{r e 0}^{*}$ と 呼んでいるが，これが同期速度より高いのは二次側の損失 を供給するためである。

図 13 は $2 \pi 69 ， 2 \pi 66 ， 2 \pi 63 \mathrm{rad} / \mathrm{s}$ のときの電圧および一 次角度波形であるが，速度が変化しても周波数が一定に制 御できていることが確認できる。

以上のことから, 回転速度変動時において, 定電压 · 定 周波数の電圧が得られることが検証できた。 


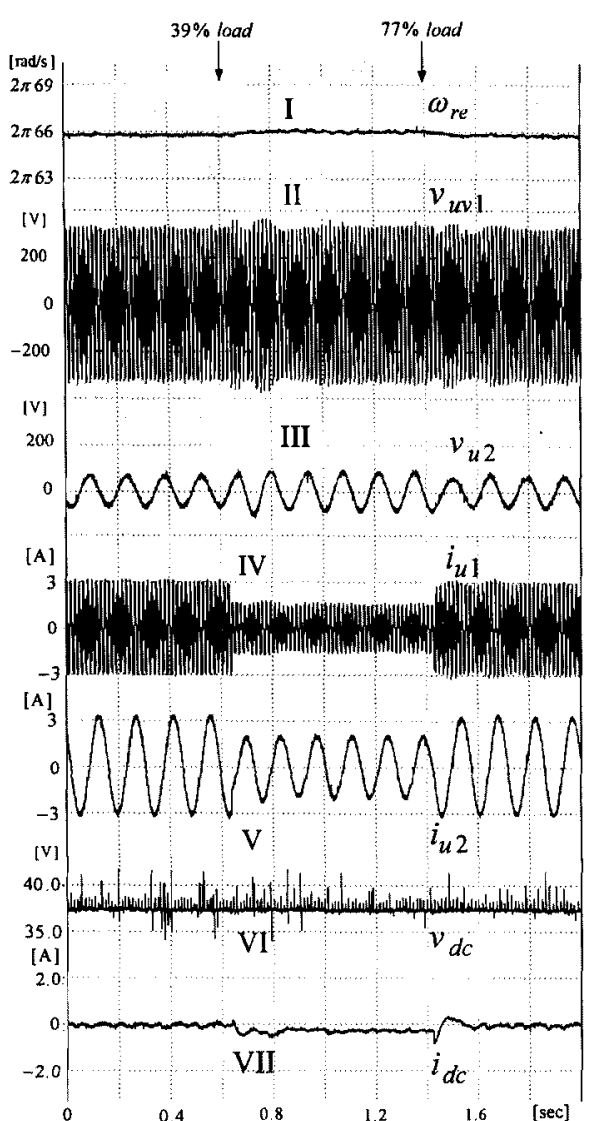

図 14 実駼結果 (負荷開閉試験)

Fig.14. Experimental results of load change test. (speed, voltage, current)

\section{$<5.2>$ 負荷開閉試験}

$77 \%$ 負荷（ $r=50 \Omega$ と $l=8.7 \mathrm{mH}$ の直列回路） $\rightarrow 39 \%$ 負荷 $(r=100 \Omega$ と $l=8.7 \mathrm{mH} \sigma$ 直列回路） $\rightarrow 77 \%$ 負荷, 上負荷を 開閉する試験を行った。その結果を図 14 に示す。

電流制御器および電圧制御器のパラメータについては前 述の<5.1>と同じ值に設定した。

II は出力電圧波形であるが, 上記の負荷変動時でも線間電 圧変動は問題のない範囲に収まり，0.2sec 程度で回復してい ることがわかる。

図 15 は無負荷における電圧および一次角度波形であり， スイッチング周波数に相当する脈動成分が重量しているが, 周波数は一定に制御できていることが確認できる。

負荷時と無負荷時における一次電圧波形の違いは以下の とおりである。T形等価回路からわかるように，無負荷時で は, 一次電流が 0 となり，二次電流による相互インダクタ ンスのドロップ分がー次電圧となる。このときの二次電流 は, 二次側インバータのスイッチング電圧により脈動分を 多く含むので，一次電圧も眽動分を含むものとなる。一方， 負荷時では，主に一次電流による負荷インピーダンスのド ロップ分が一次電圧となるが，負荷インピーダンスは相互

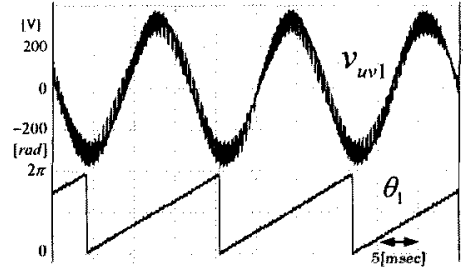

図 15 実験結果 (無負荷時)

Fig.15. Experimental results of no-load operation. (voltage, electrical angle)

インダクタンスより低いので，出力電圧脈動は少なくなる。 以上のことから，独立運転形発電システムとして必要な 諸特性を有していることが検証できた。

\section{6.おわりに}

本論文では，巻線形誘導機の二次側に直流電源をバッテ リとしたインバータを接続する独立運転形の二次励磁発電 システムについて提案し, 試作検証を行った。得られた特 徽は次のとおりである。

（1）一次角度と回転角度より計算した二次角度の制御によ り, 回転数変動の影響を全く受けない定周波数の制御采 を構成できるようになった。

(2) 二次無効分電流指令の制御により，定電圧を得ること ができ，負荷変動に強い制御系を構成できるようになっ た。

(3) マトリクス理論を適用した新しい状態方程式による二 次制御方式の構成を示し, 見通しの良い非干涉化制御系 の設計方法を提案した。

(4) 原動機の速度が変動しても, 時間平均として原動機の 速度をちょうどバッテリの充放電がバランスするよう な速度に制御することにより, 充電器が不要となるシス テムを提案した。

(5) インバータとバッテリはエンジン始動に利用でき，エ ンジン始動用の直流電動機と䨯池が要らなくなった。

(6) 巻線形誘導機の二次側インバータの容量を $10 \%$ 程度と した供試機による検証試験から，原動機の回転速度が 数\%変動しても出力周波数は全く変動しない良好な定 電圧・定周波数特性が実現できることを示した。

本論文では，負荷を抵抗とリアクトルの直列回路として いるが，その回路にコンデンサを並列接続することで出力 電圧波形の脈動成分を少なくできるとともに，励磁電流を 供給してインバー夕の励磁電流を少なくできるものと考え られる。また, 用途によっては整流器負荷など非線形負荷 における電圧歪みや三相不平衡負荷の影響も問題となる。 これらについては次の課題として㭘討する予定である。

(平成 13 年 5 月 14 日受付, 平成 14 年 2 月 12 日再受付) 


\section{付 録}

\section{1. 二次電流指令の係数}

一次電圧 $\mathbf{v}_{1}$ は( 14 )式となるが，この式には，無効成分と 有効成分の干渉に対応する $\mathbf{J}$ を含んだ項があり, これらの 項を 0 にし優れた制御特性を得るには次式のようにすれば よい。

$$
-\omega_{1}\left(l_{1}+M\right) \mathbf{J i}_{1}+\omega_{1} M \mathbf{J i}_{2}=0
$$

上式から， $\mathbf{i}_{2}=\left\{\left(l_{1}+M\right) / M\right\} \mathbf{i}_{1}$ となる。

二次電流指令を $\mathbf{i}_{2}^{*}=\left\{\left(l_{1}+M\right) / M\right\} \mathbf{i}_{1}$ とすれば，図 6 に示 すように一次電圧制御系の伝達関数を簡単にすることがで きる。

\section{2. 定数}

\section{（1）供試機定数}

定格容量：750W，定格一次電圧：200V，定格二次電圧： $100 \mathrm{~V}$, 定格一次電流: $3 \mathrm{~A}$, 定格二次電流: $6 \mathrm{~A}$, 定格周波数: $60 \mathrm{~Hz}$, 極対数: $2, R_{1}: 3.19 \Omega(7.53 \%), l_{1}: 0.015 \mathrm{H}(13.37 \%)$, $R_{2}: 4.00 \Omega(9.45 \%), l_{2}: 0.006 \mathrm{H}(13.37 \%), M: 0.280 \mathrm{H}(40.13 \%)$

\section{(2) 大形機定数}

定格容量: $100 \mathrm{~kW}$ ，定格一次電圧： $420 \mathrm{~V}$ ，定格一次電流： $190 \mathrm{~A}$ ，定格周波数: $60 \mathrm{~Hz}$ ，極対数: $2, R_{1}: 0.0515 \Omega(4.04 \%)$, $l_{1}: 0.0004 \mathrm{H}(11.82 \%), R_{2}: 0.0265 \Omega(2.08 \%), l_{2}: 0.0004 \mathrm{H}$ $(11.82 \%), M: 0.0148 \mathrm{H}(22.87 \%)$

\section{3. 高精度の速度検出法}

このシステムの回転速度はほぼ一定で, 同期速度 $1800 \mathrm{rpm}$ $=30$ 回転 $/ \mathrm{sec}$ の近くで変動する。したがってエンコーダの パルス周波数はほぼ 6000 パルス/回転 $\times 30$ 回転 $/ \mathrm{sec}=180 \mathrm{kHz}$ である。DSP の演算割り込み $500 \mu \mathrm{sec}$ の間のエンコーダの パルス数は，わずか 90 パルス（電気角で $10.8^{\circ}$ の回転角度 に相当）しか得られないので，これを用いても桁数の高い 回転速度情報は得られない。そこで，毎サンプルごとに得 られるカウンタの回転角度情報をメモリに蓄えておき，30 サンプル前すなわち $15 \mathrm{msec}$ 前の回転角度と現在の回転角度 の差をとることにより，桁数の高い速度情報を得るように している。このようにすると，15msec の間に得られるエン コーダパルスは 2700 パルス(電気角で $324^{\circ}$ の回転角度に相 当）となり，充分な桁数の速度情報を得ることができる。 本システムでは $15 \mathrm{msec}$ の間の速度変動は少ないので，その 間の平均速度を求める方法を適用することができる。

(平成 13 年 5 月 14 日受付、平成 14 年 2 月 12 日再受付)

\section{文献}

（1）安井順司・佐藤幸雄・町野毅・吉田康夫・佐野賢三・城地慎 司：「可変速揚水発電システムの開発と北海道電力（株）高 見発電所への適用」，三菱電機技法，Vol.67, No.7, pp.57-62 (1993)
（2）北英三・阪東明・桑原尚夫：「400MW 可変速揚水発電システ 厶」, 日立評論, Vol.76, No.10, pp.61-66 (1994)

（3）力石浩孝・有満稔・王毅 -上村敏 - 嶋田隆一：「交流励磁》 ライホイール発電機による高速変動負荷の補償」，電学論 D, Vol.113, No.11 (1993)

（4）金文煥・中村䝨亮・大西公平・宮地邦夫：「二次励磁誘導発 電機を用いた孤立電源用不規則入力発電システム」，電学論 D, Vol.108, No.11 (1988)

（5）川烟良尚・川上知之・川畑隆夫：「物理的意味を理解しやすく した誘導電動機の新しい状態方程式」, 計測自動制御学会論文 誌, Vol.38, No.1 (2002)

(6) 国産エンジンデータブック編集委員会著：「エンジンハンド ブック」, pp62-65

（7）日本自動車整備振興会連合会著：「講師用指導書, 二級ジー ゼル自動車」, pp114-115

（8）久下勝太郎：「誘導発電機の定周波数, 定電圧制御方式」, 電学論 B, Vol.111, No.8 (1991)

（9）五藤洋一・竹下隆晴・松井信行：「2 次励磁巻線形誘導電動機 による無効電力補償」，SPC-94-5 (1994)

川㚼良尚（正員）1970年 10 月 23 日生まれ。1999年 3 月立

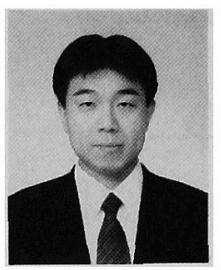
命館大学大学院理工学研究科博士後期課程修了。 同年 4 月より立命館大学理工学部電気電子工学 科 助手。2000 年 4 月より大阪府立工業高等専門 学校電子情報工学科 講師。パワーエレクトロニ クス，特に誘導機駆動に関する研究に従事，現 在に至る。博士（工学）。IEEE, 計測自動制御 学会, システム制御情報学会の会員。

森根 義久 (非会員) 1978 年 1 月 6 日生まれ。2002 年 3 月立

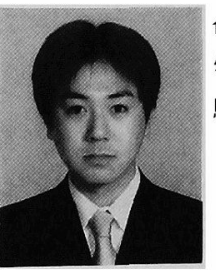
命館大学大学院理工学研究科修士課程修了。在 学中は, パワーエレクトロニクス, 特に誘導機 駆動に関する研究に従事。

岡 寿久 (非会員) 1978 年 9 月 21 日生まれ。2001 年 4 月立

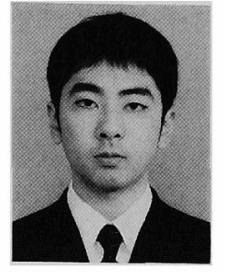
命館大学大学院理工学研究科修士課程入学。パ ワーエレクトロニクス，特に誘導機駆動に関す る研究に従事，現在に至る。

川㚼 隆夫（正員）1938 年 3 月 4 日生まれ。1960 年 3 月大阪

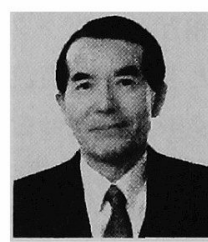
大学電気工学科卒業。同年三菱電機(株)入社。 1993 年 4 月より立命館大学理工学部電気電子工 学科教授。パワーエレクトロニクス全般の研究 に従事，現在に至る。工学博士。IEEE，EPE の 会員。 